\title{
Chapter 5 \\ Paving the Way for Effective \\ Socio-economic Rights? The Domestic \\ Enforcement of the European Social \\ Charter System in Light of Recent \\ Judicial Practice
}

\author{
Nikolaos A. Papadopoulos
}

\section{Contents}

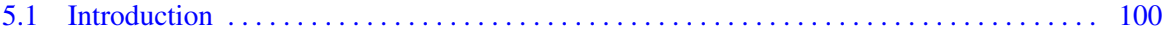

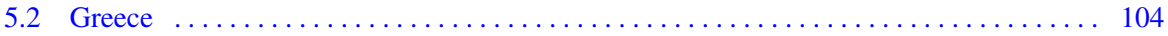

5.2.1 The Status of the European Social Charter as an International Human Rights

Treaty in the Greek Legal Order .............................. 104

5.2.2 Contesting Austerity Measures by Means of the 1961 ESC Before Greek First Instance Civil Courts . . . . . . . . . . . . . . . . . . . . . . . . . . . . . 105

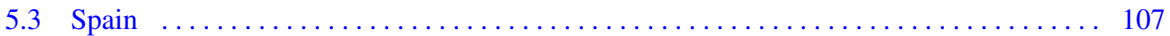

5.3.1 The Status of the European Social Charter as an International Human Rights Treaty in the Spanish Legal Order $\ldots \ldots \ldots \ldots \ldots \ldots \ldots \ldots \ldots \ldots \ldots \ldots$

5.3.2 Contesting Austerity Measures by Means of the 1961 ESC Before Spanish First

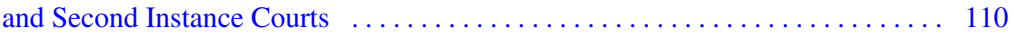

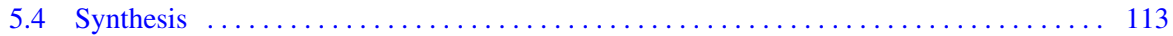

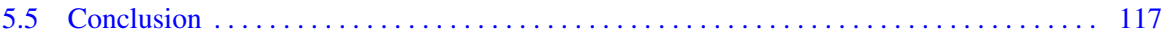

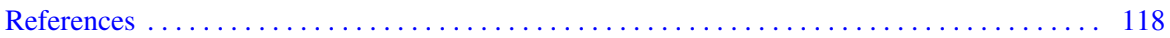

Abstract The current crisis era in Europe has revealed symptoms of lack of respect for international socio-economic rights and challenges vis-à-vis their effectiveness at the national level. One such symptom relates to the (lack of) responsiveness of domestic judges concerning the justiciability, direct applicability and enforceability of such rights. Against this background, the European Social Charter-a rather neglected legal instrument, albeit the most important one with regard to socioeconomic rights in Europe-has emerged in the jurisprudence of domestic courts in recent years, providing a unique perspective to address these challenges. In reality, even though the Charter initially seemed to exclude the possibility of being invoked before national courts, the situation has changed today. This is especially the case since the adoption of the Collective Complaints Procedure, as can be seen in the practice of lower and apex courts of several contracting parties. Specifically, various

\footnotetext{
N. A. Papadopoulos ( $\square)$

Department of International and European Law, Faculty of Law, Maastricht University,

Bouillonstraat 1-3, 6211 LH Maastricht, The Netherlands

e-mail: nikos.papadopoulos@ maastrichtuniversity.nl
} 
domestic courts - e.g. in Greece and Spain-have in many cases ruled in favour of the direct effect of various Charter provisions, and have given considerable weight to the 'quasi-case law' of the Charter's monitoring body: the European Committee of Social Rights. Domestic courts are thus providing a valuable perspective on the normative debates in legal doctrine, specifically regarding the (democratic) legitimacy of judicially reviewing the legislator's choices, and the issue of effectively protecting and enforcing international socio-economic rights at the domestic level in times of crisis.

Keywords Economic and social rights $\cdot$ European Social Charter $\cdot$ Domestic enforcement - International monitoring $\cdot$ National courts $\cdot$ Direct effect $\cdot$ Monism Effectiveness $\cdot$ Greece $\cdot$ Spain $\cdot$ Austerity $\cdot$ Financial crisis

\subsection{Introduction}

In the aftermath of the austerity-driven Sovereign Debt Crisis, and amid the coronavirus pandemic crisis, Europe is still struggling to recover from a severe crisis era. High levels of poverty, unemployment, and social exclusion have put the consensus developed under the welfare state ${ }^{1}$ and the social state principles under pressure. ${ }^{2}$ In that context, one dimension that has been considered the "obvious casualty" of this crisis era, ${ }^{3}$ is socio-economic rights as enshrined in international/regional instruments and as protected by binding positive law. ${ }^{4}$

However, even prior to the crisis, the 20th century was not entirely sympathetic towards such rights. As is well known, the challenges include the ideologically rooted ${ }^{5}$ and historically contested allegations concerning their legal nature, deeming them vague and non-justiciable principles of a programmatic nature, as opposed to civil and political rights. Particularly challenging in that respect are the normative debates surrounding the (democratic) legitimacy of judicially reviewing the legislator's socio-economic policy choices, as well as the ever-conflicting relationship of social rights with neo-liberalism. ${ }^{6}$

Even though this philosophical debate seems to be less important today, ${ }^{7}$ many challenges still remain with regard to the constitutional and judicial recognition of social rights as real and justiciable rights. ${ }^{8}$ It could thus be argued that the crisis

\footnotetext{
${ }^{1}$ De Schutter 2015, p. 126.

${ }^{2}$ Menéndez 2017, p. 73.

${ }^{3}$ Christodoulidis 2017, p. 124.

${ }^{4}$ The terms 'socio-economic rights', 'economic and social rights', and 'social rights' are used interchangeably in this chapter. Cultural rights are beyond the scope of this analysis.

${ }^{5}$ Gearty and Mantouvalou 2010.

${ }^{6}$ See e.g. MacNaughton and Frey 2018.

${ }^{7}$ See e.g. De Schutter 2013.

${ }^{8}$ Contiades and Fotiadou 2012, p. 661.
} 
in Europe has revealed only a symptom of the fact that these rights are generally ill-protected. ${ }^{9}$ Furthermore, it has also exposed the challenging issue of effectively protecting social rights at the national and international levels. After all, social rights - as all human rights - have long been facing criticism put forward by authors from various disciplinary fields. Concretely, they question whether international/regional legal instruments are actually effective and improve respect for human rights, ${ }^{10}$ but also whether litigation based on human rights (and in particular social rights) can bring about social change ${ }^{11}$ and benefit the poor and marginalised social groups. ${ }^{12}$ For the purpose of this chapter, 'effectiveness of human rights' is approached and conceived in a broad sense as social realisation (as a describable fact, reality or status) of what the notions of human rights cover, ${ }^{13}$ and as the process through which human rights causally bring about the desired change in (state or social) behaviour and policy. ${ }^{14}$

Against this background, a rather neglected ${ }^{15}$ regional legal instrument-but one of increasing importance for social rights in Europe-has come into play since the outbreak of the European Debt Crisis, providing a unique perspective to address the above-mentioned challenges to social rights, and particularly the (lack of) effectiveness of such rights at the domestic level. This particular regional legal instrument is the European Social Charter ('ESC' or 'Charter'), the legally binding ${ }^{16}$ human rights treaty ${ }^{17}$ of the Council of Europe, which guarantees economic and social rights as a counterpart to the European Convention on Human Rights ('ECHR') and a regional counterpart to the International Covenant on Economic, Social and Cultural Rights ('ICESCR').

Forty-seven states in particular are contracting parties, albeit with varying levels of commitment, to the 1961 European Social Charter or the 1996 Revised European Social Charter ('RevESC'), gradually replacing the former treaty. In addition, fifteen parties have ratified the (optional) 1995 Additional Protocol, which provides for a Collective Complaints Procedure of quasi-judicial nature. ${ }^{18}$ This procedure enables social partners and (international) NGOs holding participatory status with the Council of Europe to lodge complaints before the European Committee of Social Rights ('ECSR' or 'Committee') for rulings on possible non-implementation of the Charter in the countries concerned. Remarkably, there is no need, in that context, for the claimant organization to have exhausted domestic remedies or to be a victim of a

\footnotetext{
${ }^{9}$ O’Connell 2013, p. 60.

${ }^{10}$ See e.g. Neumayer 2005; Hafner-Burton and Tsutsui 2007; Posner 2014; Moyn 2018.

${ }^{11}$ See e.g. Rosenberg 2008.

${ }^{12}$ See e.g. Landau 2012; Cf. Bilchitz 2008.

${ }^{13}$ Millard 2008, p. 349.

${ }^{14}$ Raustiala 2005, p. 581; Hawkins and Jacoby 2010, p. 39; Krommendijk 2015, p. 492.

${ }^{15}$ De Schutter 2017, p. 11.

${ }^{16}$ Brillat 2010, p. 45.

${ }^{17}$ See ECSR, FIDH v. France, Complaint No 14/2003, decision on the merits of 8 September 2004 , para 27.

${ }^{18}$ Alston 2005, p. 58; Cullen 2009, p. 75.
} 
relevant violation. The ECSR is the Charter's supervisory body, which is composed of fifteen independent international and social law experts that have the express mandate to assess situations of compliance from a legal standpoint, and to adopt decisions concerning possible breaches of the Charter by the contracting parties. ${ }^{19}$

On the basis of the decisions adopted under the Collective Complaints Procedure, it has been argued that the Committee's "case-law without a court" ${ }^{20}$ has upgraded the Charter's monitoring mechanism, which has thus far been taking place only through the Reporting System and the Committee's 'Conclusions'. ${ }^{21}$ Furthermore, it has upgraded the ECSR's role in the European human rights protection setting and has provided new impetus to the theory and practice of effectively protecting social rights. $^{22}$

Interestingly, this development has also greatly impacted the Charter system's ${ }^{23}$ implementation by courts at the domestic level. Although the Charter was initially believed to exclude the possibility of being invoked before national courts, thus "severely limiting the attractiveness of the instrument for potential litigants", ${ }^{24}$ the situation has changed since then-especially since the adoption of the Collective Complaints Procedure. As can be observed-both in theory ${ }^{25}$ and in practice ${ }^{26}$ among lower and apex courts of several rather monist countries, ${ }^{27}$ judges rely directly on the Charter after its invocation by litigants, giving direct effect to a number of its (self-executing) provisions and granting considerable weight to the ECSR's 'quasi-case law'.28

In that context, domestic judges perceive self-executing provisions of the Charter as those that may be invoked by individuals before national courts to set aside domestic legislation, in those cases where they: (a) confer individual rights upon them ('direct effect in the narrow sense') and/or (b) contain norms that can be used as a standard for reviewing acts of national law, even if they are not formulated as individual rights ('direct effect in the broad sense'). ${ }^{29}$ In practice, they are guided

\footnotetext{
${ }^{19}$ See Article 24(2) of the 1991 Additional Protocol to the Charter.

${ }^{20}$ Akandji-Kombé 2009, p. 13.

${ }^{21}$ See e.g. Harris 2009.

${ }^{22}$ Akandji-Kombé 2005, p. 90; Nivard 2012, p. 239.

${ }^{23}$ The word 'system' points to a set of coordinated normative and institutional elements, including the substantive and procedural provisions laid down in the Charter and its Protocols, as well as the ECSR's monitoring work.

${ }^{24}$ De Schutter 2017, p. 12.

${ }^{25}$ See e.g. Akandji-Kombé 2013, p. 488.

${ }^{26}$ For French courts' relevant case law, see e.g. Mouly 2019.

${ }^{27}$ Notably, in strictly dualist states, giving direct effect to treaties is not an option in principle, since treaties are not part of domestic law unless the legislature enacts a statute to incorporate a treaty. Once a treaty has been incorporated, courts in such states apply that statute-not the treaty, at least as a formal matter, and use other techniques to harmonize domestic law with international law, such as the method of consistent interpretation (indirect effect). See Sloss and Van Alstine 2017, p. 110. ${ }^{28}$ The terms 'direct-effect', 'self-executingness' and 'direct applicability' are used interchangeably in this chapter.

${ }^{29}$ See generally Nollkaemper 2014, p. 105; Peters 2016, p. 495.
} 
by: the 'objective criterion' of direct effect, which requires a treaty provision to be clear, precise and unconditional; and the 'subjective criterion' of direct effect, which emphasises the intention of the contracting parties not to exclude such an effect by addressing states only.

In light of the above, this chapter examines the following two elements: how first and second instance national courts of selected monist contracting parties-Greece and Spain-implement and enforce the European Social Charter system; and what their differences and similarities are in that context, with respect to the 'effectiveness of human rights' as defined above. The way in which 'effectiveness of human rights' is understood within the ESC system is, essentially, in line with that working definition. More specifically, most of the articles of Part II of the RevESC commence with the words "with a view to ensuring the effective exercise" of the rights enshrined therein, followed by a series of obligations. Therefore, the use of the word 'effectiveness' in the Charter seems to refer to the exercise of a right that exists in reality, and to the guarantee that the obligations that follow are intended to ensure that a particular right will have an impact on reality. ${ }^{30}$ Moreover, the ECSR generally follows the methods of the European Court of Human Rights ('ECtHR'). It has thus-as early as in its first collective complaints decision, and later in many instances-also affirmed that "the aim and purpose of the Charter, being a human rights protection instrument, is to protect not merely theoretical but effective rights". ${ }^{31}$ The ECSR assesses the fulfilment of that objective through a variety of methods. ${ }^{32}$

Hence, this chapter employs a doctrinally comparative (international human rights) legal research lens, ${ }^{33}$ combined with socio-legal considerations, so as to answer the posed question. It focuses on recently adopted decisions of Greek and Spanish courts applying the Charter and the ECSR's 'quasi-case law', triggered by the 2008 financial crisis and specifically by labour law/market measures implemented in that context, as well as their enforcement at the state level. ${ }^{34}$

\footnotetext{
${ }^{30}$ Bétaille 2012, pp. 23-24.

${ }^{31}$ ECSR, ICJ v. Portugal, Complaint No 1/1998, decision on the merits of 9 September 1999, para 32; FEANTSA v. Slovenia, Complaint No 53/2008, decision on the merits of 8 September 2009, para 28.

${ }^{32}$ See e.g. the Committee's reasoning in FEANTSA v. France, Complaint No 39/2006, decision on the merits of 5 December 2007, paras 52-56.

${ }^{33}$ See McCrudden 2018.

${ }^{34}$ The research is grounded on a document-based desk(top) analysis of already existing legal and extra-legal data. Greek courts' decisions, as published in law journals, have been collected through the 'NOMOS' (https://lawdb.intrasoftnet.com) and the 'ISOKRATIS' (https://www.dsa net.gr) databases, and Spanish courts' decisions through the General Council of the Judiciary database (https://www.poderjudicial.es) and the Constitutional Court's database (https://hj.tribun alconstitucional.es).
} 


\subsection{Greece}

\subsubsection{The Status of the European Social Charter as an International Human Rights Treaty in the Greek Legal Order}

In light of the rather 'monist' expression of Article 28(1) of the Greek Constitution, binding international treaties that have been ratified by statute form an integral part of Greek law (automatic incorporation). These treaties are hierarchically superior to legislation and inferior to the constitution. ${ }^{35}$ In a case before the Greek courts, this ascertainment may result in the non-application of a domestic (administrative or legislative) provision, which is contrary to international treaties and therefore set aside. $^{36}$

It should be noted that Greek courts generally adhere to the direct effect doctrine, and have followed its evolution in international theory and practice relatively easily. What is more, they generally accept that an international treaty is self-executing, unless it explicitly requires states to take additional implementing measures. ${ }^{37}$ Therefore, directly applicable treaties — especially those enshrining human rights, with the ECHR being a typical example_-produce both vertical and horizontal direct effect in the Greek legal order. ${ }^{38}$

Another noteworthy fact is that in Greece, no Constitutional Court exists, while constitutional $^{39}$ and treaty-based ${ }^{40}$ review of legislative and administrative acts is (mainly) incidentally and in concreto diffused to courts at all judicial instances. Greek courts have the power to review and set aside (but not annul) - in the course of an ordinary dispute and even ex officio-a legislative provision's conformity with the Greek Constitution and ratified international human rights treaties. Finally, it is widely accepted in contemporary Greek constitutionalism that several social rights are judicially enforceable rights, and not merely social policy directives of programmatic nature.

With respect to Greece's commitment to the Charter system, it should be noted that it was among the first countries to sign the $1961 \mathrm{ESC}$, but ratified it twenty-three years later, in $1984 .{ }^{41}$ Greece has ratified all the Additional Protocols to the Charter, including the 1995 Collective Complaints Protocol. ${ }^{42}$ Greece also signed the 1996

\footnotetext{
${ }^{35}$ See Supreme Civil and Criminal Court No 1603/1991 EllDni 1993, 332; Council of State No 2281/2001 EllDni 2001, 959. See generally Yokaris 2011, p. 253.

${ }^{36}$ See Council of State No 867/1988 Arm 1988, 265.

${ }^{37}$ Yokaris 2012, p. 167.

${ }^{38}$ See Article 25(1)c of the Constitution; Supreme Civil and Criminal Court No 2159/2007 NOMOS.

${ }^{39}$ See Article 93(4) of the Constitution.

${ }^{40}$ Due to the lack of an express constitutional provision, treaty-based review is carried out on the basis of Article 28(1) of the Constitution.

${ }^{41}$ Law $1428 / 1984$.

${ }^{42}$ Law 2422/1996 and Law 2595/1998.
} 
RevESC, but did not ratify it until twenty years later, in $2016 ;{ }^{43}$ remarkably enough, this all happened during the European Debt Crisis and while far-reaching austerity measures were being implemented.

As a result, and in light of the above considerations, the ESC and its Protocolsas a binding international law treaty that was ratified by statute and automatically incorporated-forms an integral part of Greek law and prevails over provisions of Greek (primary or secondary) legislation. Hence, the rights enshrined in the Charter are in principle justiciable and-insofar as the criteria for direct effect are fulfilledthe Charter has direct effect in the domestic legal order. ${ }^{44}$ It is thus to be applied directly by national courts in vertical or horizontal disputes. ${ }^{45}$

\subsubsection{Contesting Austerity Measures by Means of the 1961 ESC Before Greek First Instance Civil Courts}

During the years of deep recession faced by Greece, ordinary courts served as a terrain for the mobilisation of litigants seeking relief from the severe consequences of austerity measures. ${ }^{46}$ In contrast to the Greek highest courts, which were initially showing signs of judicial restraint, ${ }^{47}$ lower courts were actually more receptive. This was especially the case with regard to employees in the wider public sector, who found refuge in the protection offered mainly by human rights treaty provisions.

In that context, in 2013 and 2014, various Single-Member First Instance Civil Courts $^{48}$ from different Greek regions were summoned on the basis of the interim measures procedure by local government employees, ${ }^{49}$ who were mandatorily put on 'labour reserve', an austerity measure part of the Greek bailout programmes. ${ }^{50}$ Numerous employees undertook legal action on various grounds, including Article 4(1) of the 1961 ESC ('right of workers to a remuneration that gives them and their families a decent standard of living'), seeking to have their services accepted by their employers under the pre-reserve conditions pending a final decision on their main legal action. The plaintiffs had their wages reduced by $25 \%$ - which after the reduction often resulted in wages of less than 580 euros per month, being the poverty

\footnotetext{
${ }^{43}$ Law 4359/2016.

${ }^{44}$ See e.g. with respect to Article 1(2) of the ESC, Council of State No 1571/2010 NoB, 1269.

${ }^{45}$ Apart from giving direct effect to the Charter, courts must interpret national law consistently with the Charter (in particular where national legislation exists, and its provisions are capable of such interpretation), on the basis of Article 25(1) and/or Article 2(2) of the Constitution.

${ }^{46}$ See generally Kilpatrick and de Witte 2014.

${ }^{47}$ See e.g. Papadopoulos 2020.

${ }^{48}$ In Greece there are no labour courts, therefore labour law-related disputes are resolved by civil courts, which may refuse, like all other Greek courts, to apply legislation if they find it contrary to the Constitution or to European/international law.

${ }^{49}$ The employees were under private law contracts of indefinite duration in the public sector.

${ }^{50}$ See Article 1, subparagraph Z.4-Z.2 of Law 4093/2012.
} 
line according to EUROSTAT statistics — and had their contracts terminated by the end of the one-year labour reserve period (if they were not transferred or reassigned).

Against this background, most courts responded in a rather socially protective way, by taking into consideration the crisis situation and the pressing social needs of each of the plaintiffs. Hence, in a number of decisions, ${ }^{51}$ the courts ruled that the imposed measures were contrary to the Constitution and the ECHR. Notably, in three decisions rendered in 2013, the imposed measures were deemed contrary to Article $4(1)$ of the 1961 Charter. ${ }^{52}$ It is noteworthy that in those three decisions, the courts made no reference to the ECHR, but rather plainly acknowledged the direct effect of the Charter and the self-executing character of Article 4(1); a provision which could be regarded by some as relatively vague when considered on its own. The courts thus seem to have opened the backdoor to future invocation of the Charter, either as a supplementary tool to interpret constitutional rights, or as the main legal basis.

What is even more remarkable, though, is the fact that in two out of those three decisions, the courts cite the ECSR's decision on the merits of collective complaint No 66/2011, ${ }^{53}$ in which Greece was found to be in violation of Article 4(1) of the Charter, and even without inquiring into the legal status and the normative content of the Committee's decisions. The courts therefore seem to acknowledge the ECSR's role as the authoritative interpreter of the Charter, and the key role of its 'quasi-case law' in giving substance to the Charter's provisions, especially when their wording could be regarded as relatively vague.

The Charter's contribution to challenging austerity, and particularly the measure of labour reserve-which had serious consequences for a fair percentage of the Greek public sector workforce-is demonstrated by the following effects: firstly, through the lower courts' decisions, many low-income employees who initiated interim proceedings did not lose their jobs, nor did they suffer wage reductionsat least during that initial interim period. Secondly, a new government came into power in 2015, which, through recognising inter alia the lower courts' contribution, ${ }^{54}$ repealed labour reserve provisions by law $^{55}$ and re-established posts that had been abolished. As a result, a number of employees that had been put on reserve actually returned to their posts and were able to keep their initial wages. ${ }^{56}$

\footnotetext{
${ }^{51}$ Single-Member First Instance Court of Messolonghi No 63/2013 EErgD 2013, 353; SingleMember First Instance Court of Patras No 202/2014 NOMOS; Single-Member First Instance Court of Piraeus No 2700/2013 NOMOS; Single-Member First Instance Court of Thessaloniki No 4916/2013 NOMOS; Single-Member First Instance Court of Athens Nos 1759/2013 NOMOS, 13915/2013 EErgD 2014, 547, 13917/2013 NOMOS, and 7809/2014 NOMOS.

${ }^{52}$ Single-Member First Instance Court of Chios No 37/2013 EErgD 2013, 338; Single-Member First Instance Court of Xanthi No 90/2013 EErgD 2013, 347 and Single-Member First Instance Court of Patras No 494/2013 EErgD 2014, 567.

${ }^{53}$ ECSR, GENOP-DEI/ADEDY v. Greece, Complaint No 66/2011, decision on the merits of 23 May 2012.

${ }^{54}$ See Hellenic Parliament 2015, p. 14; see also Pavlidou 2018, p. 299.

${ }^{55}$ Law 4325/2015.

${ }^{56}$ See e.g. Aftodioikisi 2013, 2015.
} 
Such an outcome alludes to the definition of the effectiveness of human rights adopted in this chapter. In particular, the right of low-income public sector employees to "a remuneration such as will give them and their families a decent standard of living", as enshrined in Article 4(1) of the Charter and as substantiated by the ECSR's interpretation, has been socially realised through the lower courts' decisions (and their enforcement), and through the government's subsequent policy actions that are causally linked to these decisions.

\subsection{Spain}

\subsubsection{The Status of the European Social Charter as an International Human Rights Treaty in the Spanish Legal Order}

Article 96(1) of the Spanish Constitution lays down the requirement for prior publication of a validly concluded international treaty in the official State Gazette, ${ }^{57}$ before it is able to produce its legal effects in the Spanish legal order and make it possible for judges to (directly) apply a treaty norm. This requirement is recognised by most authors as a material act of an administrative nature, required for the purposes of the treaty's direct internal application and the fullness of its effect in domestic law, rather than as an act of transformation of international norms into domestic ones. ${ }^{58}$ As a result, the Spanish system resembles more that of an automatic incorporation of treaties into the domestic legal order, ${ }^{59}$ and is characterised by a moderate monism. ${ }^{60}$ Furthermore, it is generally accepted that treaty provisions are considered superior to legislation and inferior to the Constitution. ${ }^{61}$ Thus, in the case of a potential conflict between a treaty provision and domestic law, which is a matter for all ordinary courts - rather than the Constitutional Court—-to decide upon under treaty-based review ('control de convencionalidad'), ${ }^{62}$ the law should be disapplied (but not annulled) and the treaty should be applied.

\footnotetext{
${ }^{57}$ See Article 1(5) of the Spanish Civil Code.

${ }^{58}$ Iglesias Velasco 2013, p. 185.

${ }^{59}$ Remiro Brotóns 1997, p. 359.

${ }^{60}$ Torres Pérez 2013.

${ }^{61}$ See Article 31 of Law 25/2014 ('Treaties and other International Agreements'). See also Article 95(1) of the Constitution.

${ }^{62}$ See Spanish Constitutional Court, 20 December 2018, STC 140/2018-ECLI:ES:TC:2018:140. This is based inter alia on Article 96 combined with Article 10(2) of the Constitution. See generally Jimena Quesada 2018.
} 
Notably, the Spanish Constitution contains an opening clause ${ }^{63}$ to international human rights treaty law, ${ }^{64}$ which results in the obligation for Spanish courts to take the latter into account when interpreting fundamental rights and freedoms under the Constitution. Remarkably enough, when it comes to the issue of direct effect of international treaties in the Spanish legal order, this is regulated by Article 30(1) of Law 25/2014, which stipulates: "International treaties will be of direct application, unless it is clear from the text that such application is conditional on the adoption of laws or provisions of relevant regulations". ${ }^{65}$ In addition, as accepted in the earlier case law of Spanish courts, when the content of international treaty provisions is precise, complete and unconditional, and rights arise for individuals, treaty rules can be invoked before Spanish courts and produce direct effect. ${ }^{66}$ Finally, as in Greece-it is a common view in Spanish constitutionalism that several social rights are in principle judicially enforceable rights rather than merely aspirational and programmatic principles.

Moreover, it is crucial to highlight a recent development in the case law of the Spanish Supreme Court, which is highly relevant for the effectiveness of human rights, as it concerns the legal value attributed by Spanish courts to the output of human rights treaty monitoring bodies. In judgment No 63/2018, ${ }^{67}$ which has been described as a turning point in the engagement of Spanish courts with such bodies, ${ }^{68}$ the Supreme Court addressed a number of important considerations concerning the Views of the Committee on the Elimination of Discrimination Against Women ('CEDAW Committee') rendered on the basis of individual and group communications. These considerations may also be relevant, to some degree, to the pronouncements of other treaty monitoring bodies such as the ECSR's collective complaints decisions.

Specifically, the Supreme Court relied on the above-mentioned constitutional provisions and pointed out the guarantees of the communications procedure (e.g. express regulation, Spain's participation in the proceedings). The Supreme Court thus considered that there can be no doubt that the Committee's Views, especially those delivered in the case of the appellant, ${ }^{69}$ are of a "binding/obligatory" nature for the contracting party that has recognised the CEDAW Convention and its Optional

\footnotetext{
${ }^{63}$ Saiz Arnaiz 1999.

${ }^{64}$ Article 10(2): "Provisions relating to the fundamental rights and liberties recognised by the Constitution shall be construed in conformity with the Universal Declaration of Human Rights and international treaties and agreements thereon ratified by Spain".

${ }^{65}$ Unofficial translation.

${ }^{66}$ See e.g. Constitutional Court, 23 November 1981, STC 38/1981-ECLI:ES:TC:1981:38; Supreme Court (Contentious-Administrative Chamber-6th), 22 April 2010, STS 2223/2010ECLI:ES:TS:2010:2223.

${ }^{67}$ Supreme Court (Contentious-Administrative Chamber-4th), 17 July 2018, STS 2747/2018ECLI:ES:TS:2018:2747.

${ }^{68}$ Gutiérrez Espada 2018.

${ }^{69}$ CEDAW Committee, Angela González Carreño v. Spain, Communication No 47/2012, decision of 16 July 2014.
} 
Protocol providing for the complaints mechanism. Such an obligatory character derives from Article 24 of the Convention, according to which state parties "undertake to adopt all necessary measures at the national level aimed at achieving the full realization of the rights recognized in the present Convention" ${ }^{70}$ Therefore, even though - as noted by the Supreme Court - the CEDAW Convention does not oblige contracting parties to adopt any specific procedures to give effect to the Views of its monitoring body, the absence of such a specific procedure amounts to a breach of Spain's constitutional mandate. Notwithstanding, the Supreme Court also suggested that the applicability of its reasoning was limited to this specific case-and to cases concerning the pecuniary liability of the state. ${ }^{71}$

Concerning Spain's commitment to the Charter system, it should be noted that being a self-proclaimed social and democratic State, ${ }^{72}$ Spain has signed and ratified the 1961 ESC $^{73}$ in addition to the 1988 and the 1991 Protocols. ${ }^{74}$ However, for a long time, Spain did not sign nor ratify the 1995 Collective Complaints Protocol, perhaps fearing the ECSR's dynamic interpretation of the Charter provisions under the collective complaints procedure. Furthermore, in 2000, the country signedbut did not ratify - the 1996 RevESC. Spain's failure to ratify the RevESC and the Collective Complaints Protocol has been fiercely criticised within academic circles. ${ }^{75}$ The Spanish state on 4 February 2021 signed the Collective Complaints Protocol and has recently taken steps to ensure that these ratifications will take place in the near future. $^{76}$

It can be concluded from the above analysis that the $1961 \mathrm{ESC}$ is a legally binding international treaty that has been published in the Spanish Gazette, and thus produces its effects in the Spanish legal order. In addition, it prevails over legislation and is capable of producing direct effect, as long as the relevant criteria are fulfilledeither in vertical or horizontal disputes. Finally, the Charter and the pronouncements of its monitoring body may serve as an important tool in defining and interpreting socio-economic rights and freedoms under the Constitution.

\footnotetext{
${ }^{70}$ Notably, the ESC also contains in para 1 of Part 1 a very similar provision, albeit with a less assertive wording.

${ }^{71}$ See generally Kanetake 2019.

${ }^{72}$ See Article 1(1) of the Constitution.

73"Instrumento de Ratificación de 29 de abril de 1980, de la Carta Social Europea, hecha en Turín de 18 de octubre de 1961".

74“Instrumento de Ratificación por parte de España del Protocolo Adicional a la Carta Social Europea, hecho en Estrasburgo el 5 de mayo de 1988".

${ }^{75}$ See e.g. Brillat 2009, p. 231.

${ }^{76}$ On 10 November 2020, the Spanish government approved an agreement providing for the referral of the RevESC to the Parliament for ratification and also authorising the expression of Spain's consent to be bound by that Charter as well as the Collective Complaints Protocol.
} 


\subsubsection{Contesting Austerity Measures by Means of the 1961 ESC Before Spanish First and Second Instance Courts}

On 19 November 2013, in a widely discussed decision, the Social Court of Barcelona was asked by the plaintiff to declare the unfairness of his dismissal. ${ }^{77}$ The dismissed worker's full-time open-ended employment contract 'for support of entrepreneurs' had been terminated by the defendant's company, as the worker did not pass the trial period of maximum one year, set in accordance with Article 4(3) of Royal DecreeLaw 3/2012. ${ }^{78}$ This concerned an austerity measure resembling the one implemented in Greece in response to the ongoing crisis. ${ }^{79}$

The Court initially laid down the facts of the case and the relevant provisions of the Royal Decree-Law, and concluded without further ado that these provisions had to be evaluated for their conformity with the 1961 ESC and the 1988 Protocol, which Spain has ratified. The court also noted Spain's failure to ratify the RevESC and the Collective Complaints Protocol. It then stated that the Charter is an international norm that forms part of internal law according to Articles 10(2) and 96 of the Constitution, and thus has the same binding value as the Treaties of the EU, hierarchically ranked above national law. ${ }^{80}$ Remarkably, the Court went on to apply Article 4(4) of the Charter ('right of all workers to a reasonable period of notice for termination of employment') directly and, in fact, in a horizontal dispute.

The Court subsequently made a significant statement that would mark the beginning of a new era for Spanish courts regarding the application of the ESC system; namely, that the ECSR is responsible for ensuring the correct application of the Charter, and that its decisions are therefore "binding" on national courts and constitute "case law" that must be applied by the latter. The affirmation of this rather striking position in the present ruling but also in many rulings that followed, led the Court to refer to and thoroughly analyse the ECSR's findings in its collective complaints decisions concerning Greece, ${ }^{81}$ even though Spain had not ratified the relevant Protocol. In the cited collective complaints decision, Greece was found to be in violation of Article 4(4) of the Charter, as it did not provide a notice period (or compensation) when the employer terminated the employment contract prior to the end of the one-year trial period.

Notably, the Court did not stop there; although it recognised that the Royal DecreeLaw at stake was dictated amid an economic crisis, it rather adopted the ECSR's reasoning in its Conclusions under the Reporting System, in which the Committee

\footnotetext{
${ }^{77}$ Social Court of Barcelona-2nd ['Juzgado de lo Social'], No 412/2013, 19 November 2013, SJSO 63/2013-ECLI:ES:JSO:2013:63.

${ }^{78}$ This contract is a full/part time open-ended one establishing a probationary period of 12 months during which a worker can be dismissed without any notice or compensation. See generally Salcedo Beltran 2013.

${ }^{79}$ See Article 17(5) of Law 3899/2010 and Section 1, subsection IA of Law 4093/2012.

${ }^{80}$ See also Articles 29, 30 and 31 of Law 25/2014 supra note 61.

${ }^{81}$ ECSR, GENOP-DEI and ADEDY v. Greece, Complaint No 65/2011, decision on the merits of 23 May 2012.
} 
asserted its famous non-regression stance towards social rights in the face of the crisis. ${ }^{82}$ These considerations led the Court to conclude that the situation in that above-mentioned collective complaints decision was identical to the case brought before it. The Court therefore ruled that Article 4(3) of Royal Decree-Law 3/2012 was in violation of Article 4(4) of the ESC, a higher-ranking rule, for not establishing a period of notice for the termination of the employment contract during the oneyear trial period. Also, such a long trial period cannot in any case be considered reasonable.

Remarkably, this pronouncement was endorsed in the years that followed by many other Social Courts, ${ }^{83}$ but also by a number of Autonomous Communities' High Courts of Justice, at second instance, ${ }^{84}$ which shared the position of Barcelona's court. These courts also affirmed that Part II of the Charter is binding on Spain, and that Article 4(4) of the Charter is sufficiently precise and unconditional on its own, and as interpreted by the ECSR - in contrast to other provisions that have not passed the scrutiny of the ECSR's interpretation. Therefore, Article 4(4) of the ESC enshrines a specific right attributed to workers, and not merely state obligations. Evidently, High Courts of Justice provide a thoughtful observation in that context; namely that a right that has passed the ECSR's interpretive filter is likely to be considered sufficiently precise. Such an observation may prove to be crucial when domestic judges assess whether or not a treaty provision fulfils the objective criterion of direct effect.

Moreover, in this case, the judges based their argumentation on the Committee's Conclusions XX-3 concerning Spain, which were issued on 5 December 2014, and in which the fact that during their trial period, employees under contracts 'for support of entrepreneurs' may be dismissed without notice, was inter alia found not in conformity with Article 4(4) of the 1961 Charter. By doing so, they asserted that the fact

\footnotetext{
${ }^{82}$ See ECSR, General Introduction to Conclusions XIX-2 (2009).

${ }^{83}$ Social Court of Toledo-1st, No 667/2014, 27 November 2014, SJSO 183/2014ECLI:ES:JSO:2014:183; more recently Social Court of Barcelona-23rd, 12 March 2018, SJSO 1483/2018-ECLI:ES:JSO:2018:1483 and Social Court of Talavera de la Reina-3rd, No 152/2018, 29 June 2018, SJSO 4856/2018-ECLI:ES:JSO:2018:4856. See also the following decisions, not available at https://www.poderjudicial.es, cited in the ECSR's 2015 Activity Report, https://rm.coe.int/CoERMPublicCommonSearchServices/DisplayDCTMContent?docume ntId $=09000016805 \mathrm{ab} 9 \mathrm{c} 7$, p. 120, accessed 10 February 2020: "Employment tribunal-no. 1 of Tarragona no. 179, 2 April 2014-Employment tribunal-no. 1 of Mataró no. 144, 29 April 2014Employment tribunal-no. 3 of Barcelona no. 352, 5 November 2014-Employment tribunal-no. 19 of Barcelona no. 491, 17 November 2014-Employment tribunal-no. 9 of Gran Canaria no. 705, 31 March 2015-Employment tribunal-no. 2 of Fuerteventura no. 58, 31 March 2015-Employment tribunal-no. 1 of Toledo no. 202, 9 April 2015-Employment tribunal-no. 1 of Las Palmas no. 74, 11 May 2015-Employment tribunal-no. 1 of Las Palmas no. 896, 3 June 2015”.

${ }^{84}$ High Court of Justice ['Tribunal Superior de Justicia'] of Las Palmas de Gran Canaria (Social Chamber-1st), Decisions No 30/2016, 28 January 2016, STSJ ICAN 1420/2016ECLI:ES:TSJICAN:2016:1420, No 252/2016, 30 March 2016, STSJ ICAN 829/2016ECLI:ES:TSJICAN:2016:829, No 342/2016, 18 April 2016, STSJ ICAN 1598/2016ECLI:ES:TSJICAN:2016:1598 and No 73/2017, 31 January 2017, STSJ ICAN 547/2017ECLI:ES:TSJICAN:2017:547; High Court of Justice of Valladolid (Social Chamber-1st), Decisions No 01497/2016, 26 June 2016, STSJ CL 3026/2016-ECLI:ES:TSJCL:2016:3026 and No 02077/2016, 19 December 2016, STSJ CL 4707/2016-ECLI:ES:TSJCL:2016:4707.
} 
that Spain has not yet ratified the Collective Complaints Protocol, does not mean that the content of the ESC is not binding, or that it can exonerate them from the judicial application of its provisions. ${ }^{85}$ The Charter's value in that context was confirmed by the fact that — as pointed out by the High Courts of Justice — the establishment of a one-year trial period in the employment contract is not in violation of the Constitution, according to the Constitutional Court's relevant case law. ${ }^{86}$ However, no reference to the ESC was included in the Constitutional Court's reasoning in those cases. The consequence of these considerations was that the Royal Decree-Law provision in question was declared-by the first and second instance courts-inapplicable and the contested dismissals were declared null and void.

It should, however, be noted that there were also a few decisions by resistant Social Courts and High Courts of Justice on the issue, in which judges were reluctant to recognise the direct effect of the Charter and the value of the ECSR's output. Consequently, the judges found no breach of Spain's international obligations, and validated the legality of Article 4(3) of the Royal Decree-Law in the cases brought before them. ${ }^{87}$ It seems that resistance to the Charter's direct effect, and effective enforcement by Spanish courts, is exemplified inter alia by the argument put forward by some judges to deny the Charter system's value — particularly at second instance ${ }^{88}$ — that Spain has not ratified the RevESC and the Collective Complaints Protocol. This situation of contradicting sentences between Social Chambers of High Courts of Justice on the same issue reached the Spanish Supreme Court, starting in 2015, under appeals for 'unification of doctrine', 89 which were, however, declared inadmissible..$^{90}$

Therefore, in such cases where constitutional (and EU law) social rights protection is deemed inadequate, the Charter can serve as a minimum tool of effective protection through the recognition of the direct effect (of several) of its provisions, and as interpreted by the ECSR. This becomes especially apparent when considering that the Spanish Constitutional Court is not competent to review the compatibility of legislation with international treaties, which is the responsibility of ordinary courts.

However, in terms of the effectiveness of human rights, as defined in this chapter, a number of reserved observations can be made. On the one hand, it is true that the dismissed employees who won their cases before Social Courts and/or High Courts

\footnotetext{
${ }^{85}$ See e.g. Social Court of Barcelona-23rd, 12 March 2018, SJSO 1483/2018ECLI:ES:JSO:2018:1483.

${ }^{86}$ Constitutional Court, 16 July 2014, STC 119/2014-ECLI:ES:TC:2014:119, 22 January 2015, STC 8/2015-ECLI:ES:TC:2015:8, 22 June 2015, STC 140/2015-ECLI:ES:TC:2015:140.

${ }^{87}$ See e.g. Social Court of Badajoz-1st, No 62/2018, 2 February 2018, SJSO 374/2018-ECLI: ES:JSO:2018:374; High Court of Justice of Barcelona (Social Chamber-1st), No 4090/2015, 22 June 2015, STSJ CAT 6721/2015-ECLI:ES:TSJCAT:2015:6721.

${ }^{88}$ See e.g. High Court of Justice of Coruña (Social Chamber-1st), No 625/2017, 30 January 2017, STSJ GAL 662/2017-ECLI:ES:TSJGAL:2017:662.

${ }^{89}$ That is a procedure established under Articles 218-228 of Law 36/2011 ('Regulating Social Jurisdiction'), which may be applicable when there is a diversity of judicial responses dealing with substantially equal facts, grounds, and claims of the same or other litigants.

${ }^{90}$ See e.g. Supreme Court (Social Chamber-1st), 7 February 2017, ATS 1120/2017ECLI:ES:TS:2017:1120A.
} 
of Justice and who did not have those decisions overturned by the latter, ultimately returned to their jobs-provided that the decisions were executed. Thus, relying directly on the Charter as interpreted by the ECSR, Spanish courts proved crucial in assisting those employees to realise their right to a reasonable notice period for termination of employment, in times of crisis and unemployment. On the other hand, however, there were also a number of cases in which either Social Courts outright rejected the applicants' pleas, or where High Courts of Justice overturned the positive decisions of the Social Courts. In these cases, many workers were prevented from realising their Charter rights, thus forming part of a two-speed category of workers.

This outcome unequivocally demonstrates the limitations to the effectiveness of human rights that one may encounter when resorting only to courts to claim a socioeconomic right. Nevertheless, as transpired from the Greek case discussed above, the positive decisions of the Spanish courts-in conjunction with the criticism put forward by trade unions and academics — contributed to prompting the newly elected Spanish Government to repeal by law ${ }^{91}$ Article 4(3) of Royal Decree-Law 3/2012, and the particular contract providing for a one-year trial period. Therefore, the Charter system has causally contributed to a significant policy change for workers' rights, from which a considerable part of the Spanish workforce benefits. Ultimately, this development serves as another domestic example of the Charter system's contribution to the affirmation of the effectiveness of human rights.

\subsection{Synthesis}

It is important to note, first of all, that even though Greece had not ratified the RevESC, and Spain remained at the lowest level of commitment towards the ESC system when most of the analysed decisions were adopted, the judicial practice of their first and second instance courts should be perceived as an example of dynamic and effective application of the ESC system. Such practice is facilitated, on the one hand, by the rather monist conception of the relationship between international and national law, as well as the supremacy of international law over statutory law, which prevail in the constitutions of both jurisdictions. On the other hand, it is facilitated by their ordinary courts' competence to carry out treaty-based review of legislation on labour law-related issues.

However, having a monist system in which direct effect of international treaties is possible, does not necessarily mean that international human rights will be more effectively protected in such a jurisdiction. In practice, courts in both monist and dualist states can achieve roughly the same results with respect to the effectiveness of human rights by applying a treaty either directly or indirectly, as long as they are receptive to human rights treaties' domestic judicial application, and recognise the supremacy of international law over statutory law. Since courts in monist states generally prefer applying a treaty indirectly rather than directly, and usually deny

${ }^{91}$ Royal Decree-Law 28/2018. 
the self-executing character of treaty provisions requiring further legislative implementation, the practical significance of the traditional distinction between monism and dualism has become eroded. ${ }^{92}$ Therefore, the monist-dualist distinction offers a useful - albeit imperfect-starting point to examine whether international human rights are effective at the domestic level. ${ }^{93}$

Nevertheless, as the Greek and Spanish lower courts' practice has shown, when the domestic legal system makes treaty law directly applicable and superior to national legislation, the judiciary can be expected to become more directly involved in a state's policy process. What is more, it may prove to be a powerful way to force states to change their policy, on the basis of human rights treaties, as interpreted by their monitoring bodies-especially in countries with a strong rule of law system in which states generally comply with court orders. ${ }^{94}$

The above-described judicial practice of Greek and Spanish first and second instance courts also showcases their responsiveness towards international socioeconomic rights, and in particular their justiciability, which is one of the conditions for the effectiveness of these rights - on an equal footing with civil and political rights, and even in horizontal disputes. Moreover, the courts have greatly contributed to the effectiveness of the ECSR's monitoring practices at the domestic level and the full realisation of Charter rights-especially labour rights. This is illustrated by the fact that owing to the ECSR's collective complaints decisions, which give precise and 'authentic' meaning ${ }^{95}$ to the Charter provisions following the interpretive methods of international law, ${ }^{96}$ Greek judges, on the one hand, granted great weight ${ }^{97}$ and took due consideration of those decisions within the meaning of the interpretation rules of customary international law laid down in Articles 31 and 32 of the Vienna Convention on the Law of Treaties ('VCLT'). ${ }^{98}$

On the other hand, Spanish judges applied the ECSR's collective complaints decisions directly as an autonomous and freestanding legal basis, and not merely as a tool to supplement the construction of formal law, or to confirm the court's

\footnotetext{
${ }^{92}$ Sloss 2012, p. 375.

${ }^{93}$ Verdier and Versteeg 2017, p. 174.

${ }^{94}$ Brewster 2017, p. 66.

${ }^{95}$ Remarkably, the ECSR's power to guide the interpretation of the Charter's provisions is not only founded explicitly in the text of the Treaty and its Protocols but is also articulated in a very clear way, as opposed to other international human rights monitoring bodies. In addition, according to a view, this affirmation results in a procedural obligation for domestic courts to acknowledge that power and give serious consideration to the ECSR's collective complaints decisions, or else provide compelling reasons and counterarguments in case of disagreement. See Articles 10 and 12 of the 1995 Additional Protocol to the Charter in conjunction with Article 24(2) of the 1961 ESC, as amended by Article 2 of the 1991 Additional Protocol.

${ }^{96}$ See e.g. ECSR, World Organisation against Torture (OMCT) v. Italy, Complaint No 19/2003, decision on the merits of 7 December 2004, para 41.

${ }^{97}$ See on this International Court of Justice, Ahmadou Sadio Diallo (Republic of Guinea v. Democratic Republic of the Congo), Merits, Judgment, I.C.J. Reports 2010, p. 639, para 66.

${ }^{98}$ Either as an interpretation accepted by parties through "subsequent practice in the application of the treaty" (Article 31(3)b VCLT) or as supplementary interpretive means (Article 32 VCLT).
} 
position in an ancillary way-as is usually the rule in such cases where courts do not point-blank ignore treaty bodies' output. ${ }^{99}$ There is no question that both Greek and Spanish courts provide high degrees of legitimacy ${ }^{100}$ to the ECSR; Spanish judges, nevertheless, pay attention not so much to the reasonableness or persuasiveness of the ECSR's monitoring work, ${ }^{101}$ but rather to its binding or obligatory nature. As a result, they seem to assimilate the legal nature of the ECSR's collective complaints decisions with that of international/regional courts' judgments, such as those of the ECtHR, ${ }^{102}$ to offer them full legal force.

Consequently, such exceptional application by domestic courts of international instruments (such as the ECSR's decisions and conclusions) that are predominantly regarded as non-binding (soft law), ${ }^{103}$ helps to integrate those instruments into part of formal international law (hard law). ${ }^{104}$ This outcome should be considered remarkable for domestic courts that engage with human rights treaty monitoring bodies. Admittedly, a critic could argue that such practice constitutes interference-by the courts-with the matters of domestic political bodies; Spanish courts in particular are granting binding interpretive authority to the ECSR, which was not-at least explicitly-foreseen by the contracting states when signing the Charter. However, in the case of Spain, this practice seems to be ex post validated to some degree by the reasoning that the Spanish Supreme Court provided in its above-mentioned 2018 judgment, in which the Views of the CEDAW Committee were deemed legally binding.

It is very likely that Greek and Spanish judges' recourse to such interpretive practice may reflect, on the one hand, a recognition of the methodological rigour and sound argumentation exercised by the ECSR in its monitoring work, as well as a reaffirmation of the quasi-judicial character of the collective complaints procedure. On the other hand, however, it perhaps also represents an indication of the strong impact that the Eurozone crisis-and the legislative changes that it precipitatedexerted on the reasoning of Greek and Spanish judges. This is amplified by the fact that the ECSR's collective complaints decisions concerning austerity measures in Greece-which received wide attention across Europe-had a significant impact on the reasoning of Spanish courts, ${ }^{105}$ even though Spain had-at the time-not expressed its intention to be bound by the Collective Complaints Protocol. Interestingly, the impact of the collective complaints decisions against Greece on the reasoning of Spanish courts was far greater than their impact on the case law of Greek courts.

\footnotetext{
${ }^{99}$ Kanetake and Nollkaemper 2014, p. 774.

${ }^{100}$ See generally Petersen 2012, p. 231; Mechlem 2009, p. 908.

${ }^{101}$ See Flanders 2009.

${ }^{102}$ Borlini and Crema 2020.

${ }^{103}$ Van Alebeek and Nollkaemper 2012, p. 356.

${ }^{104}$ Kanetake and Nollkaemper 2014, p. 806; Shelton 2012, p. 575.

${ }^{105}$ See also e.g. Social Court of Barcelona-12th, No 287/2015, 4 September 2015, SJSO 60/2015ECLI:ES:JSO:2015:60, relying on the ECSR's decisions on the merits of collective complaints Nos 76-80/2012, which concerned social security and pension reforms in Greece.
} 
What is more, in contrast to the Spanish Supreme Court's recognition of binding inter partes effect on the CEDAW Committee's Views in the above-described judgment, a fair number of Spanish lower courts seem to recognise that the Charter's treaty body decisions produce a binding erga omnes effect, and-to a great extenta res interpretata effect. Despite Spain not being formally bound by the Collective Complaints Protocol and the ECSR's decisions, the resemblance of the austerity measure implemented in Greece to the one implemented in Spain, may have been another factor that explains the reliance of Spanish judges on the ECSR's decision against Greece in that context. Notwithstanding, such remarkable practice could, understandably, be criticised for also being at odds with the 'pacta sunt servanda' principle.

Thus, the measure imposing a one-year trial period, during which a worker can be dismissed without any notice (or compensation), has been implemented both in Greece and Spain during the crisis. The measure has, paradoxically, been found to be in breach of the Charter, as interpreted by the ECSR, only by Spanish courts. Although Greece has ratified the relevant Protocol and has been found by the ECSR to be in breach of the Charter in that regard, no Greek court to date has come to such a conclusion, thus negating - together with the executive and the legislature-the effects of the Charter system.

All things considered, the judicial practice of Greek and Spanish courts has also exposed the limitations to the effectiveness of human rights that individuals may encounter when litigating before domestic courts, in order to claim socio-economic rights enshrined in international treaties, or to contest austerity measures. The first significant limitation is the fact that, in the cases examined, the social realisation of the Charter rights was ultimately dependent on the State's actions-either by enforcing the courts' positive decisions, or by repealing the laws on which the contested measures were based. Therefore, the effectiveness of socio-economic rights may principally be a matter of political will and commitment, thus requiring other means of exerting political pressure besides litigation. Domestic courts' (direct) application of the ESC system causally contributed to inducing the Greek and Spanish executives to change their policy in accordance with the Charter's standards and workers' needs. Nonetheless, it was a change in government that proved to be the actual turning point.

The second major limitation to the effectiveness of socio-economic rights that becomes apparent in that context, includes (in)equality as well as legal and social cohesion. ${ }^{106}$ Specifically, the persons who initially benefited from the Greek and Spanish courts' positive decisions on the basis of the ESC system, were only those who had the necessary resources (e.g. financial means, proper information) to bring proceedings before the courts. ${ }^{107}$ Those employees who were affected by the contested legislative measures and who did not—or could not—-file a lawsuit, or who were rejected protection either at first or second instance, lost their jobs (without notice or compensation) and were left in the grip of austerity's implications. Until the contested laws were repealed a few years later by newly elected governments (with

${ }^{106}$ Pavlidou 2018, p. 299.

${ }^{107}$ See Landau 2012, p. 191; Tushnet 2012, p. 156. 
different political and social agendas), those employees were denied the enjoyment and realisation of their rights, and it was only through governmental policy-making that they were given the opportunity to make that a reality. In any case, the risk of a new government explicitly resisting those effects may always be present.

\subsection{Conclusion}

This chapter has demonstrated the European Social Charter system's potential to contest the well-known criticisms of social rights, serving as the last bastion for lowincome members of society, and as an important tool in the hands of national courts for the reaffirmation of justiciable and effective social rights at the domestic level. That is especially the case for Greek and Spanish lower courts, which have relied directly on the Charter provisions, and have given considerable weight or legal value to the pronouncements of the European Committee of Social Rights; and indeed, in times of crisis, a time when the legislature's leeway in the field of social policy is rather restricted and financial resources are limited.

Hence, through that pathway, the courts, in the examined cases, managed to prevent many Greek and Spanish low-income employees from losing their jobs and salaries in times of widespread unemployment and assist them in realising their rights, as enshrined in the ESC. Through their decisions, those courts have also contributed to policy change, causally inducing states to take (legislative) action and to accomplish challenging tasks that they had thus far been unwilling to undertake. In that context, the courts' practice in applying international social rights standards throughout the crisis - to double-check the legislature's choices and actions and to stimulate policy and social change — could be assimilated to Rosenberg's dynamic court model. ${ }^{108}$ The courts specifically refrained from adopting a restrained approach ${ }^{109}$ and chose to also take into consideration the social and political contexts. Regardless of the outcomes of the cases brought before them, they understood the reality in which they work; this made the courts relevant and effective in contributing to respect for human rights at the domestic level, ${ }^{110}$ and to inducing the desired change in state behaviour-in accordance with the legal standards deriving from the ESC system.

To conclude, the lower courts of Greece and Spain have-to a considerable degree-paved the way for effective socio-economic rights at the domestic level, and have set a precedent that could be followed by courts of other contracting parties to the ESC, or to other treaties, in their subsequent practice. Although workers' mobilisation before domestic courts may also face a number of limitations and a fair

\footnotetext{
${ }^{108}$ Rosenberg 2008.

${ }^{109}$ Tushnet 2008.

${ }^{110}$ Cavallaro and Brewer 2008, p. 770.
} 
amount of political resistance to the effectiveness of human rights, Greek and Spanish lower courts on their part have contributed to closing the gap between rhetoric and practice, and to making socio-economic rights a lived reality.

\section{References}

Aftodioikisi (2013) Chios: A definite return of the IDAX-DE; a fine to the municipality if they do not accept them, https://www.aftodioikisi.gr/ota/dimoi/xios-epistrofi-oristika-ton-idax-de-pro stimo-sto-dimo-ean-den-tous-dexthei/ (in Greek), accessed 10 February 2020

Aftodioikisi (2015) With the Parliament's seal the re-employment of employees in the public sector-157 'YES' from SYRIZA-ANEL to the Katrougalos bill, https://www.aftodioikisi.gr/ipo urgeia/kai-me-ti-voula-tis-voulis-oi-epanaproslipseis-sto-dimosio-157-nai-apo-siriza-anel-stonomosxedio-katrougkalou/

Akandji-Kombé J-F (2005) The material impact of the jurisprudence of the European Committee of Social Rights. In: de Búrca G, de Witte B, Ogertschnig L (eds) Social Rights in Europe. Oxford University Press, Oxford, pp 89-108

Akandji-Kombé J-F (2009) Les réclamations collectives dans le cadre de la Charte sociale européenne: bilan et perspectives. Europe des droits et libertés 28, available at: https://www. europedeslibertes.eu/ accessed 18 November 2020

Akandji-Kombé J-F (2013) La justiciabilité des droits sociaux et de la Charte Sociale Européenne n'est pas une utopie. In: Akandji-Kombé J-F (ed) L'homme dans la société internationale: Mélanges en hommage au Professeur Paul Tavernier. Bruylant, Brussels, pp 475-503

Alston P (2005) Assessing the strengths and weaknesses of the European Social Charter's supervisory system. In: de Búrca G, de Witte B, Ogertschnig L (eds) Social rights in Europe. Oxford University Press, Oxford, pp 45-67

Bétaille J (2012) Les conditions juridiques de l'effectivité de la norme en droit public interne, illustrations en droit de l'urbanisme et en droit de l'environnement. Université de Limoges, Limoges

Bilchitz D (2008) Poverty and Fundamental Rights: The Justification and Enforcement of SocioEconomic Rights. Oxford University Press, Oxford

Borlini L, Crema L (2020) The legal status of decisions by human rights treaty bodies: Authoritative interpretations or mission éducatrice? In: Ziccardi Capaldo G (ed) The Global Community Yearbook of International Law and Jurisprudence 2019. Oxford University Press, Oxford, pp $129-158$

Brewster R (2017) The effectiveness of international law and stages of governance. In: Sandholtz W, Whytock C (eds) Research Handbook on the Politics of International Law. Edward Elgar Publishing, Cheltenham, pp 55-78

Brillat R (2009) La Charte sociale et son acceptation progressive par les États. RevEurDerFund $13: 227-243$

Brillat R (2010) The European Social Charter and Monitoring its Implementation. In: Aliprantis N, Papageorgiou I (eds) Social rights: Challenges at European, Regional and International Level. Bruylant, Brussels, pp 43-59

Cavallaro J, Brewer S (2008) Reevaluating Regional Human Rights Litigation in the Twenty-First Century: The Case of the Inter-American Court. AJIL 102:768-827

Christodoulidis E (2017) Social Rights Constitutionalism: An Antagonistic Endorsement. JLawSoc 44:123-149

Contiades X, Fotiadou A (2012) Social rights in the age of proportionality: Global economic crisis and constitutional litigation. IJConstL 10:660-686

Cullen H (2009) The collective complaints system of the European Social Charter: Interpretative methods of the European Committee of Social Rights. HRLRev 9:61-93 
De Schutter O (ed) (2013) Economic, Social and Cultural Rights as Human Rights. Edward Elgar Publishing, Cheltenham

De Schutter O (2015) Welfare State Reform and Social Rights. NQHR 33:123-162

De Schutter O (2017) The European Social Charter as the Social Constitution of Europe. In: Bruun N, Lörcher K, Schömann I, Clauwaert S (eds) The European Social Charter and the Employment Relation. Hart Publishing, Oxford, pp 11-51

Flanders C (2009) Toward a Theory of Persuasive Authority. OklLawRev 62:55-88

Gearty C, Mantouvalou V (2010) Debating Social Rights. Hart Publishing, London

Gutiérrez Espada C (2018) La aplicación en España de los dictámenes de comités internacionales: la STS 1263/2018, un importante punto de inflexión. CDT 10:836-851

Hafner-Burton EM, Tsutsui K (2007) Justice Lost! The Failure of International Human Rights Law to Matter Where Needed Most. JPeaceRes 44:407-425

Harris D (2009) Collective Complaints under the European Social Charter: Encouraging Progress? In: Warbrick C, Kaikobad K, Bohlander M (eds) International Law and Power: Perspectives on Legal Order and Justice: Essays in Honour of Colin Warbrick. Martinus Nijhoff, Leiden, pp 3-24

Hawkins D, Jacoby W (2010) Partial Compliance: A Comparison of the European and InterAmerican Courts of Human Rights. JILIR 6:35-86

Hellenic Parliament-Scientific Department (2015) Report on Draft Bill "Democratization of Administration-Fighting Bureaucracy and E-Government-Restitution of Injustices and other Provisions". https://www.hellenicparliament.gr/UserFiles/7b24652e-78eb-48079d68-e9a5d4576eff/e-dioikisi-epi.pdf accessed 10 February 2020 [Bov $\lambda \hat{\eta} \tau \omega \nu$ E $\lambda \lambda \eta \tilde{\eta} \omega \nu$ -

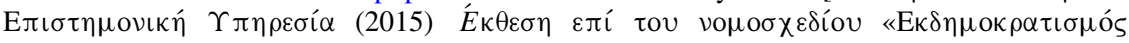

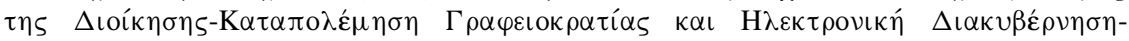

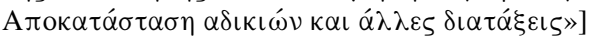

Iglesias Velasco AJ (2013) Reflexiones sobre la implementación de los tratados internacionales por los tribunales domésticos: especial referencia a España. AnuEspDerInt 29:165-216

Jimena Quesada L (2018) El control de convencionalidad y los derechos sociales: nuevos desafíos en España y en el ámbito comparito europeo (Francia, Italia y Portugal). AnuIberoamdeJusticiaConst 22:31-58

Kanetake M (2019) María de los Ángeles González Carreño v. Ministry of Justice. AJIL 113:586592

Kanetake M, Nollkaemper A (2014) The Application of Informal International Instruments Before Domestic Courts. GeoWashInt'lLRev 46:765-807

Kilpatrick C, de Witte B (2014) A Comparative Framing of Fundamental Rights Challenges to Social Crisis Measures in the Eurozone. EJSL 2014:2-11

Krommendijk J (2015) The domestic effectiveness of international human rights monitoring in established democracies. The case of the UN human rights treaty bodies. RevIntOrgan 10:489-512

Landau D (2012) The reality of social rights enforcement. HarvIntlLJ 5:190-247

MacNaughton G, Frey F-F (eds) (2018) Economic and social rights in a neoliberal world. Cambridge University Press, Cambridge

McCrudden C (2018) Comparative international human rights law: A justification and an agenda for the future. In: Roberts A, Stephan PB, Verdier PH, Versteeg M (eds) Comparative international law. Oxford University Press, Oxford, pp 439-458

Mechlem K (2009) Bodies and the interpretation of human rights. VJTL 42:905-947

Menéndez A (2017) The Crisis of Law and the European Crises: From the Social and Democratic Rechtsstaat to the Consolidating State of (Pseudo-)technocratic Governance. JLawSoc 44:56-78

Millard E (2008) L'effectivité des droits de l'homme. In: Andriantsimbazovina J, Gaudin H, Marguenaud J-P, Rials S, Sudre F (eds) Dictionnaire des droits de l'homme. PUF, Paris, pp $349-352$

Mouly J (2019) La barémisation des indemnités prud'homales: un premier pas vers l'inconventionnalité? DrSoc 2:122-129 
Moyn S (2018) Not Enough: Human Rights in an Unequal World. Harvard University Press, Cambridge, MA

Neumayer E (2005) Do International Human Rights Treaties Improve Respect for Human Rights? JCR 49:925-953

Nivard C (2012) La justiciabilité des droits sociaux: étude de droit conventionnel européen. Bruylant, Brussels

Nollkaemper A (2014) The Duality of Direct Effect of International Law. EJIL 25:105-125

O'Connell P (2013) Let them eat cake: Socio-economic rights in an age of austerity. In: Nolan A, O’Connell R, Harvey C (eds) Human Rights and Public Finance: Budgets and the Promotion of Economic and Social Rights. Hart Publishing, Oxford, pp 59-76

Papadopoulos NA (2020) Austerity-Based Labour Market Reforms in Greece v. Fundamental Rights in the Aftermath of the European Debt Crisis: An Analysis of Supranational and National Bodies' Jurisprudence. EurPubLaw 26:421-450

Pavlidou K (2018) Social rights in the Greek austerity crisis: Reframing constitutional pluralism. IJPL 10:287-321

Peters A (2016) Beyond Human Rights: The Legal Status of the Individual in International Law. Cambridge University Press, Cambridge, UK

Petersen N (2012) Determining the Domestic Effect of International Law through the Prism of Legitimacy. ZaöRV 72:223-259

Posner E (2014) The Twilight of Human Rights Law. Oxford University Press, Oxford

Raustiala K (2005) Form and substance in international agreements. AJIL 99:581-614

Remiro Brotóns A (1997) Derecho internacional. McGraw-Hill, Madrid

Rosenberg G (2008) The Hollow Hope. Can Courts Bring About Social Change? University of Chicago Press, Chicago

Saiz Arnaiz A (1999) La apertura constitucional al derecho internacional y europeo de los derechos humanos. El artículo 10.2 de la Constitución española. Consejo General del Poder Judicial, Madrid

Salcedo Beltran C (2013) El contrato de apoyo a emprendedores su difícil encaje en la normativa internacional, europea y nacional. RevDerSoc 62:93-122

Shelton D (2012) The legal status of normative pronouncements of human rights treaty bodies. In: Hestermeyer H, Wolfrum R (eds) Coexistence, Cooperation and Solidarity: Liber Amicorum Rüdiger Wolfrum. Martinus Nijhoff, Boston, pp 553-575

Sloss D (2012) Domestic application of treaties. In: Hollis D (ed) The Oxford Guide to Treaties. Oxford University Press, Oxford, pp 367-395

Sloss D, Van Alstine M (2017) International law in domestic courts. In: Sandholtz W, Whytock CA (eds) Research Handbook on the Politics of International Law. Edward Elgar Publishing, Cheltenham, pp 79-115

Torres Pérez A (2013) El impacto del derecho internacional de los derechos humanos en España. In: Bandeira Galindo GR, Urueña R, Torres Pérez A (eds) Protección multinivel de derechos humanos. dhes. Red de Derechos Humanos y Educación Superior, Barcelona, pp 417-434

Tushnet M (2008) Weak Courts, Strong Rights: Judicial Review and Social Welfare Rights in Comparative Constitutional Law. Princeton University Press, Princeton

Tushnet M (2012) A response to David Landau. HarvIntlLJOnline 53:155-164

Van Alebeek R, Nollkaemper A (2012) The legal status of decisions by human rights treaty bodies. In: Cheltenham Keller H, Ulfstein G (eds) UN human rights treaty bodies: Law and legitimacy. Cambridge University Press, Cambridge, UK, pp 356-413

Verdier P, Versteeg M (2017) Modes of domestic incorporation of international law. In: Sandholtz W, Whytock C (eds) Research Handbook on the Politics of International Law. Edward Elgar Publishing, Cheltenham, pp 149-175

Yokaris A (2011) Greece. In: Shelton D (ed) International Law and Domestic Legal Systems: Incorporation, Transformation, and Persuasion. Oxford University Press, Oxford, pp 249-258 
Yokaris A (2012) The practice of jurisdictional bodies in the application of international law.

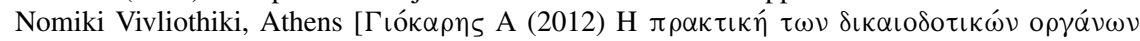

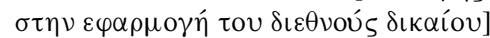

Nikolaos A. Papadopoulos is a Ph.D. Candidate at the Department of International and European Law of Maastricht University. He holds an LLB (magna cum laude) from the European University of Cyprus, a BSc in Political Science and Public Administration from the University of Athens and an LLM (cum laude) from the European Law School of Maastricht University. His research examines the dynamics of the European Social Charter for the protection of economic and social rights in Europe. He is under the supervision of Professors Bruno de Witte and Anne Pieter van der Mei. Currently, Nikolaos has an appointment as International Consultant to the Council of Europe - Department of the European Social Charter and he is also an associate at a law firm based in Athens, specialising in public and social law. The completion of this chapter was funded by the State Scholarships Foundation of Greece (IKY) under its scholarship programme in cooperation with the National Bank of Greece (NBG). 